\title{
Letter to ESEX
}

\section{Recent behaviour of the Debeli Namet glacier, Durmitor, Montenegro}

\author{
Philip. D. Hughes* \\ Geography, School of Environment and Development, The University of Manchester, UK
}

* Correspondence to: Philip D. Hughes, Geography, School of Environment and Development, Oxford Road, The University of Manchester, MI 3 9PL, UK.

E-mail:

philip.hughes@manchester.ac.uk

Received 6 February 2007;

Revised 2 April 2007;

Accepted 23 April 2007

\begin{abstract}
A small cirque glacier is present in a north-east facing cirque on the mountain of Šljeme (2455 $\mathrm{m}$ a.s.l.) in the Durmitor massif, Montenegro. Sediment ridges in front of this glacier are interpreted as moraines and can be attributed to recent glacier activity over the past 130 years. Lichenometry was applied to determine the relative ages of different moraines using Aspicilia calcarea agg. One set of moraines dates from about $1878 \mathrm{AD}$, whilst another set of inner moraines dates from about $1904 \mathrm{AD}$. The most recent moraines appear to have formed within the last 11 years in front of an active glacier margin. Copyright @ 2007 John Wiley \& Sons, Ltd.
\end{abstract}

Keywords: glacier; Dinaric Alps; Montenegro; lichenometry; Aspicilia calcarea

\section{Introduction}

Only 100 years ago, glaciers were much more extensive than at present in many high mountain areas of the Mediterranean, such as in the Sierra Nevada, Spain (Gómez et al., 2003), the Picos de Europa (González-Trueba, 2004), the Pyrenees (Gellatly et al., 1992; Grove and Gellatly, 1995; Grove, 2004), the Alpes Maritimes (Federici and Pappalardo, 1995; Federici and Stefanini, 2001) and the Italian Appenines (Federici, 1979; Gellatly et al., 1994; D'Orefice et al., 2000; Giraudi, 2005). In many of these areas, the glaciers have since completely disappeared. Many of these Mediterranean glaciers advanced during the Little Ice Age (1550-1850 AD), which was a significant climatic event for geomorphology and culture in the Mediterranean region (Grove, 2001; Xoplaki et al., 2001). However, many European glaciers have also advanced in the last 156 years (Grove, 2004) and it would be incorrect to consider the post-Little Ice Age period as one characterized by continuous glacier retreat. This paper reports evidence of glacier activity from the late 19th Century to the present in the Durmitor massif, Montenegro (Figure 1).

There are only a few reports of recent glaciation in the Balkans. The most intensive research has focused on the Zeleni Sneg glacier on Mount Triglav, in the mountains of Slovenia. By 1995 the glacier covered an area of only $0.0303 \mathrm{~km}^{2}$ (Gabrovec, 1998). Increases in summer temperatures and maximum daily temperatures from May to September between 1954 and 1994 are closely correlated with the retreat of the glacier front and reduced ice thickness (Gams, 1994).

Further south, in the mountains of Bulgaria, Louis (1930) identified 11 glaciers at altitudes between 2650 and $2925 \mathrm{~m}$ a.s.l. (see also Hubbard, 1932). The state of these glaciers is unclear, although the author is unaware of any more recent reports on these features or their sites. However, Velchev (1999) recently reported (in Bulgarian) on 'new' periglacial forms on the highest mountain Musala (2925 m a.s.1.). Numerous early 20th century glaciers in the Balkans were also reported by Roth von Telegd (1923), who mapped the presence of 20 glaciers in the high cirques of the Prokletije Mountains on the Montenegro-Albania border (Figure 1). The largest glaciers extended over $1 \mathrm{~km}$ in length in the north-western cirques of Maja Jezerce (2692 m a.s.l.), the highest peak of this range. The modern state of these glaciers is unknown.

Elsewhere in Montenegro, there have been no reports of glaciers. However, Nicod (1968) presented a photograph of a 'moraine de névé' in the Karlica cirque below the north-facing cliffs of Šlijeme (2455 m a.s.l.) in the Durmitor massif, Montenegro. The term 'moraine de névé' is often used to refer to a protalus or pronival rampart and usually implies formation by nival processes (e.g., Gignoux, 1946; Shakesby et al., 1995; Serrano and González-Trueba, 

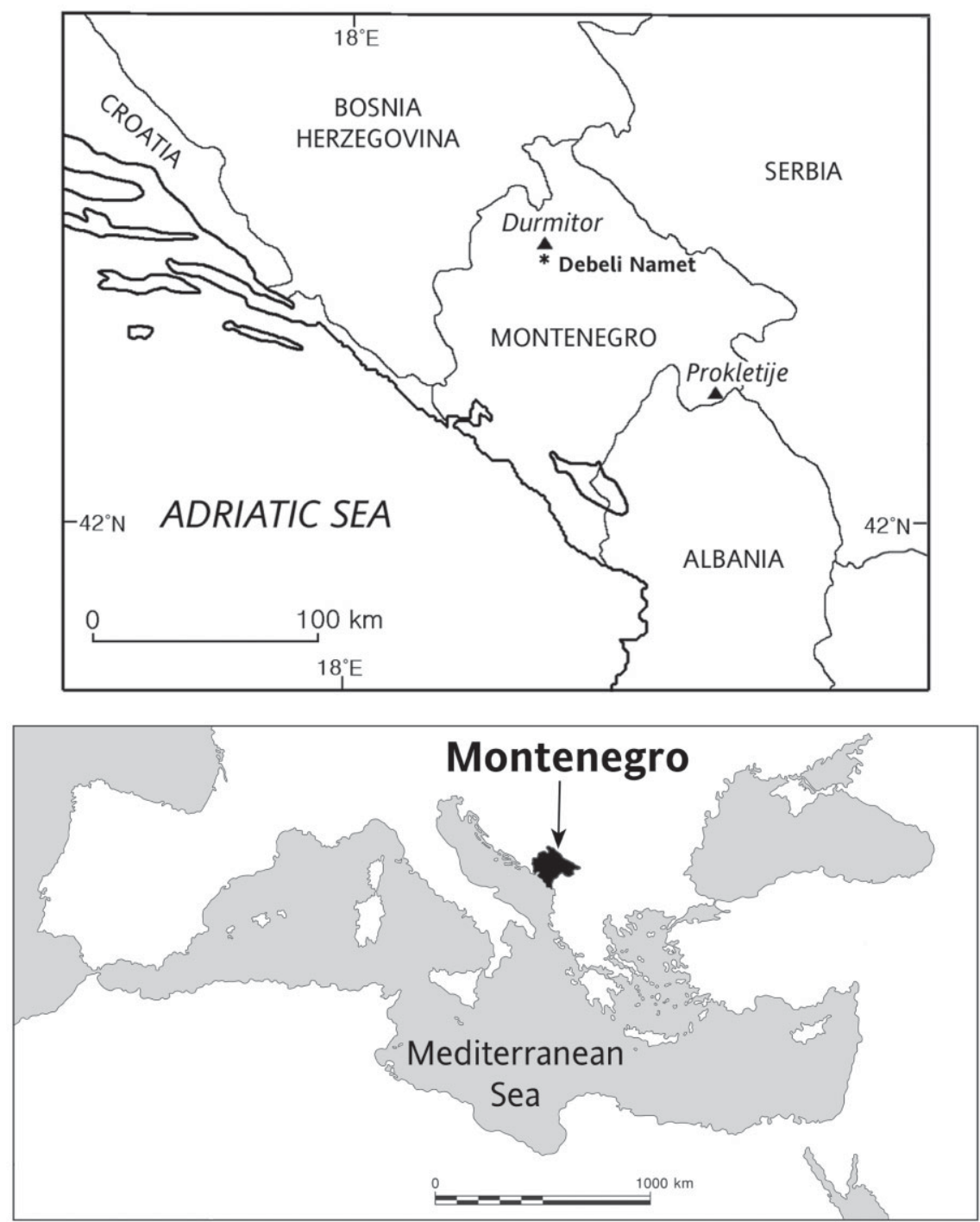

Figure I. The location of the Debeli Namet site in Montenegro and the wider Mediterranean region.

2005, Figure 2). The head of this cirque is known by the local name Debeli Namet (translated from Serbian to English as thick drift). This site is the focus of this paper, which has three principal aims. These are to

(i) examine evidence of modern glacier activity in the Karlica cirque,

(ii) examine evidence for former glacier activity in the Karlica cirque and

(iii) estimate the age of different moraines in the Karlica cirque using lichenometry.

\section{Study Area}

The Karlica cirque is situated on the north-east face of Sljeme ( $2455 \mathrm{~m}$ a.s.l.) in the Durmitor massif in northern Montenegro (Figure 1). The massif comprises 48 peaks over $2000 \mathrm{~m}$ formed in Triassic and Jurassic limestones, culminating at Bobotov kuk (2523 m a.s.l.). At Zabljak (1450 m a.s.l.), the mean annual precipitation is about $1500 \mathrm{~mm}$, with a mean annual temperature of $0{ }^{\circ} \mathrm{C}$ and a mean summer (June/July/August) temperature of $11.5^{\circ} \mathrm{C}$ (Cerović, 1986). Large areas of Montenegro were glaciated on multiple occasions during the Pleistocene. Durmitor has been subjected to intense glacial erosion and moraine systems are frequently well preserved (Nicod, 1968; Marovic and Markovic, 1972). 


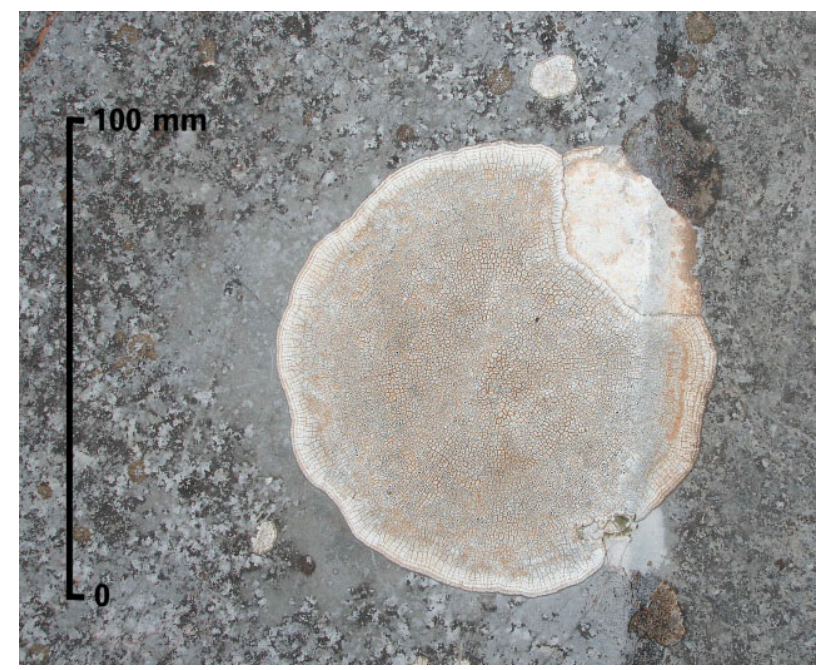

Figure 2. The lichen species Aspicilia calcarea agg. used for lichenometry in this study. This figure is available in colour online at www.interscience.wiley.com/journal/espl

\section{Methods}

\section{Geomorphological mapping}

The distribution of snow and ice at the Debeli Namet site at the head of the Karlica cirque was mapped on to 1:25 000 topographic base maps at the end of the melt seasons in October 2005 and September 2006. Spatial variability in the composition of snow and ice was examined by digging pits, 1-2 $\mathrm{m}$ in depth, at $100 \mathrm{~m}$ intervals along a transect from the lowest area of snow and ice to the headwall. Pits were dug since substantial layers of surface hoar frost frequently masked the true composition of the subsurface material.

Sediment ridges in the Karlica cirque were also mapped. Surface sediments were sampled at random from these ridges and 50 clasts were analysed for roundness and surface textural features such as striae. Clast roundness was assessed using descriptive criteria covering the range very angular to well rounded (Evans and Benn, 2004).

\section{Lichenometry}

The white crustose lichen species Aspicilia calcarea agg. (Figure 2) was used to establish the lichen size/age relationship for the Durmitor area, Montenegro. This lichen has a whitish-grey thallus and is common on limestone rocks of the Mediterranean region. Maas and Macklin (2002) established a statistically significant 100-year linear growth regression for this species and applied it to date recent flooding in Crete.

The lichen species Aspicilia calcarea agg. was identified using detailed photographic and descriptive keys (e.g. Botanic Garden and Botanical Museum Berlin-Dahlem, 2007). The thallus diameter of Aspicilia calcarea agg. was measured on 50 gravestones and monuments of known age in 10 different localities at altitudes between 1400 and $2200 \mathrm{~m}$. The lichen size/age relationship was obtained by plotting the mean of the five largest lichen thalli (Matthews, 2005), taken from a total sample size of at least 30 lichens measured at random from each of the 50 gravestones and monuments. This method has been shown to offer one of the most reliable estimates of moraine and tombstone dates (Jomelli et al., 2007). Care was taken to use gravestones and monuments composed of local limestone bedrock identical to that found in the Karlica cirque.

The diameters of Aspicilia calcarea agg. thalli were then measured on surface clasts on sediment ridges at the head of the Karlica cirque. Lichens were chosen towards the top of boulders away from the effects of prolonged snow cover, which can inhibit lichen growth (Benedict, 1991; Innes, 1985a). The mean diameter of the five largest thalli from a random sample of at least 30 lichens was calculated for each sediment ridge and then compared with the lichen size/age relationship established from the gravestone and monument lichen data to determine the approximate age of the landform. 


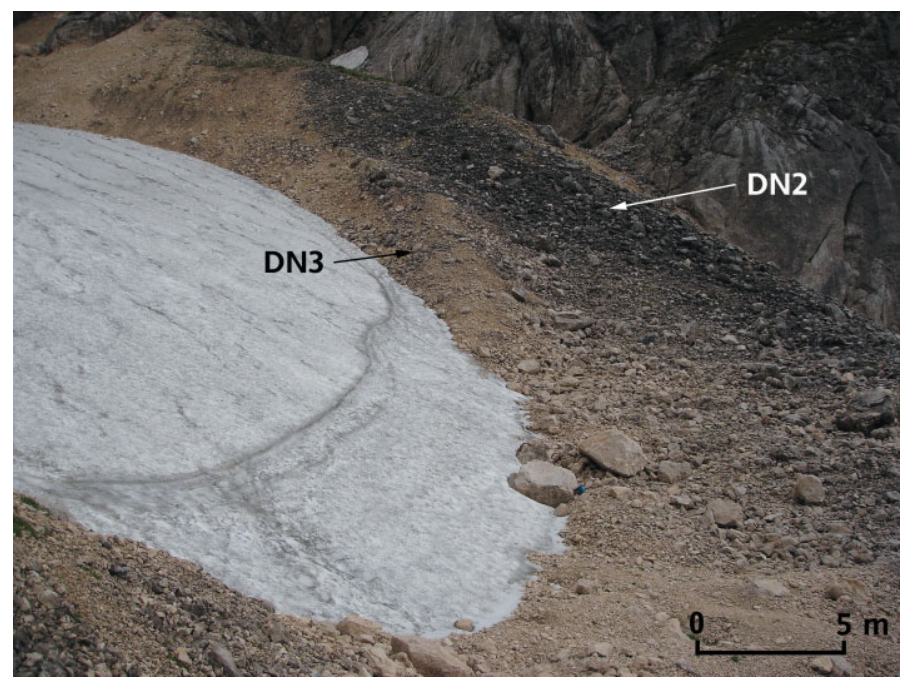

Figure 3. The Debeli Namet glacier and moraine ridges DN2 and DN3 (September 2006). This figure is available in colour online at www.interscience.wiley.com/journal/espl

\section{Results}

\section{Geomorphological mapping}

Snow and ice at the Debeli Namet site at the head of the Karlica cirque (about $43^{\circ} 06^{\prime} 50^{\prime \prime} \mathrm{N}, 19^{\circ} 04^{\prime} 25^{\prime \prime} \mathrm{E}$ ) covered an area of about 5 hectares $\left(0.05 \mathrm{~km}^{2}\right)$ between about 2100 and $2200 \mathrm{~m}$ altitude at the end of the melt season in September 2006. The upper cirque area was formed entirely of ice in the lower half, and of ice covered by snow drifts 2-3 $\mathrm{m}$ thick in the upper half. The mean altitude of the transition between snow and ice at the end of the melt season in 2006 was estimated at about 2150 metres based on 1:25 000 topographic maps. The lower ice surface was characterized by irregularly spaced $(20-50 \mathrm{~m})$ convex bands of sediment rich ice (Figure 3 ). These dark bands were 300 $500 \mathrm{~mm}$ wide and consisted of alternating micro-bands of 'clean' and 'dirty' ice, the latter about 50-100 mm wide and the former about $10-30 \mathrm{~mm}$ wide.

In September 2006, three sediment ridges were present in the foreland of the Debeli Namet (Figure 4). The outermost sediment ridge crest (DN1) was situated about $50 \mathrm{~m}$ from the modern ice margin (Figure 5). A second sediment ridge (DN2) was situated about 25-30 m from the glacier margin and a third ridge crest (DN3) was situated only 1-2 $\mathrm{m}$ from the lower ice margin at the head of the cirque (Figure 3 ).

On all three sediment ridges, clasts were predominantly subrounded (DN1, 80\%; DN2, 80\%; DN3, 60\%) and all sediment ridges contained clasts with striae. Interestingly, stratigraphically older sediment ridges contained fewer clasts displaying striae (D1, 30\%; D2, 40\%; D3, 60\%).

\section{Lichenometry}

A linear regression of lichen diameter data from 50 gravestones and monuments at a range of altitudes is presented in Figure 6. Surface age based on dated gravestones and monuments is the independent variable $(x)$ and lichen size is the dependent variable (y) (e.g., Federici and Stefanini, 2001). It would not be strictly correct to do the reverse, i.e. have lichen size as the independent variable $(x)$ and surface age as the dependent $(y)$, even though the ultimate objective is to be able to solve surface age from known lichen sizes. Nevertheless, values of surface age $(x)$ can be estimated to solve known values of lichen size $(y)$. The regression $R^{2}$ value of 0.93 illustrates that there is a strong, statistically significant, linear relationship between lichen size (mean of the five largest thalli) and surface age. The regression relationship between lichen size and lichen age is defined by the equation

$$
Y=-8.26+0.74 X \quad\left(R^{2}: 0.93\right)
$$

where $Y$ is lichen diameter (mean of five largest) (mm) and $X$ is surface age (years).

Lichen measurements on the three moraine ridge crests are presented in Table I. The mean of the five largest lichens on the outermost moraine ridge (DN1) was $86.8 \mathrm{~mm}$. The mean of the five largest lichens on the second moraine 


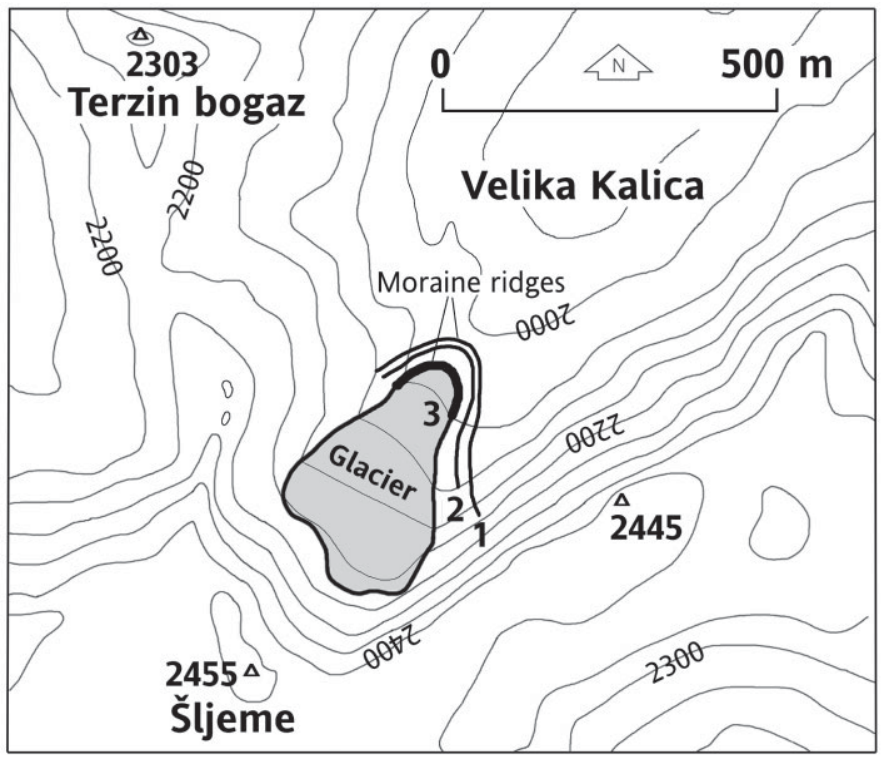

Figure 4. Geomorphological map depicting the Debeli Namet glacier (grey shading) and the moraines DNI, DN2 and DN3 (numbered on map - I, outermost moraine; 3 , innermost moraine).

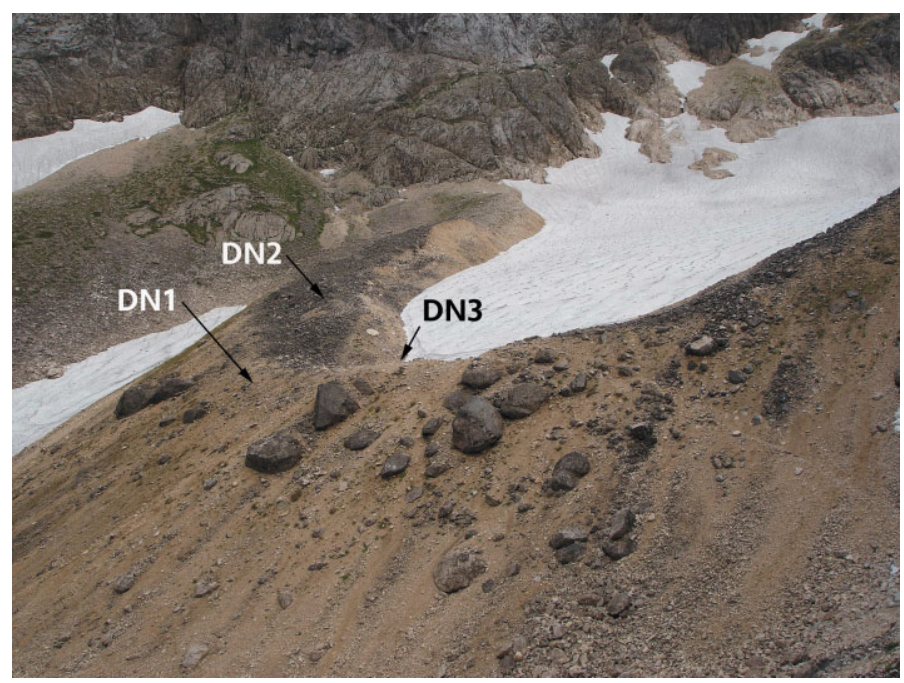

Figure 5. The Debeli Namet glacier and foreland moraines. The moraine ridges DNI, DN2 and DN3 are labelled (September 2006). This figure is available in colour online at www.interscience.wiley.com/journal/espl

Table I. Lichenometry results from three moraine crests in front of the Debeli Namet glacier, Montenegro

\begin{tabular}{lcc}
\hline Site & $\begin{array}{c}\text { Mean of five largest } \\
\text { lichens, } \mathbf{m m} \text { [sample size] }^{\text {Estimated age using }}\end{array}$ & $\begin{array}{c}\text { Eschen-age regression } \\
\text { lichen }\end{array}$ \\
\hline Moraine DN3 & No lichens & $<11 \cdot 2$ years \\
Moraine DN2 & $67 \cdot 5^{[50]}$ & 1904 \\
Moraine DN1 & $86 \cdot 8^{[50]}$ & 1878 \\
\hline
\end{tabular}




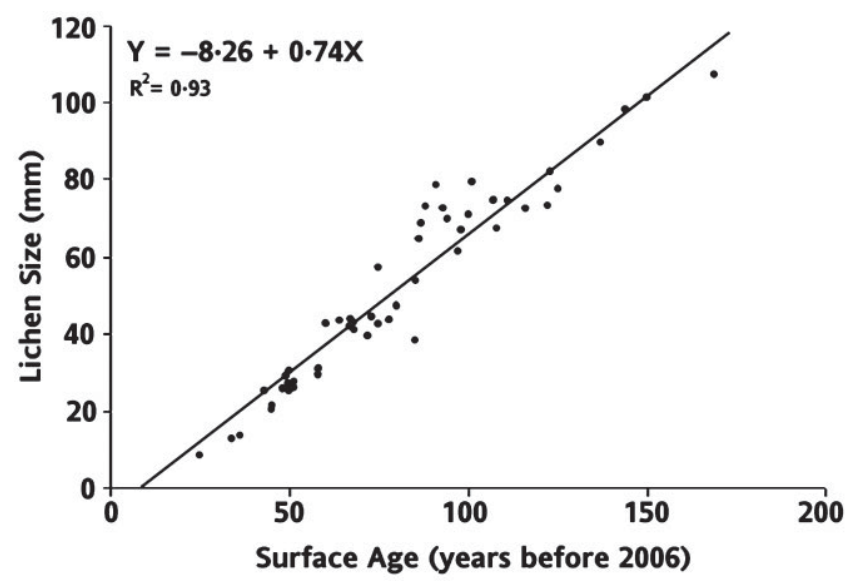

Figure 6. Regression of surface age against the mean size of the five largest lichen thalli (50 samples) obtained by measuring lichens on monuments and gravestones of known age.

(DN2) was $67.5 \mathrm{~mm}$. No lichens were present on the innermost moraine (DN3). The corresponding age estimates for these lichen measurements based on Equation (1) are presented in Table I.

\section{Discussion}

\section{The significance of the geomorphological evidence}

The Debeli Namet site at the head of the Karlica cirque is interpreted as an active glacier. The transition between surface snow and ice at about $2150 \mathrm{~m}$ a.s.l. identified at the end of the melt season in 2006 is interpreted as representing the contemporary equilibrium line altitude. At latitude $43^{\circ} 06^{\prime} 50^{\prime \prime} \mathrm{N}$ it is one of the southernmost glaciers in Europe, and is situated just less than $1^{\circ}$ further north of the southernmost glacier, the Ghiacciaio del Calderone in Italy at $42^{\circ} 28^{\prime} 15^{\prime \prime} \mathrm{N}$ (D'Orefice et al., 2000). It is also the largest reported glacier in the Balkans (about $0.05 \mathrm{~km}^{2}$ ), nearly 2 hectares larger than the more northerly Zeleni Sneg glacier $\left(1995\right.$ glacier area $\left.=0.0303 \mathrm{~km}^{2}\right)$ on Mount Triglav, in the mountains of Slovenia (Gabrovec, 1998).

There are convex bands of sediment rich ice (Figure 3) on the lower ice surface. These features are consistent with variations in ice velocity across the glacier, with the fastest flow away from the ice margins. The presence of deformed layers is important since it indicates that the ice is actively deforming and thus supports the interpretation of the Debeli Namet feature as a true glacier. The irregular spacing of these bands of sediment-rich ice may reflect high interannual variability in accumulation and flow due to avalanching.

The geomorphology in the foreland of the modern Debeli Namet glacier clearly identifies three episodes of moraine building and glacier front stabilization or advance (Figures 3-5). These ridges are all arcuate forms more than $500 \mathrm{~m}$ from the cirque back wall and the sedimentology of these ridges clearly supports their interpretation as moraines formed by a small cirque glacier. The collective classification of these ridges by Nicod (1968) as a 'moraine de névé', which suggests a mode of formation by a snow patch and not a glacier, is incorrect. However, a combination of both nival and glacial processes probably contributed to the formation of the sediment ridges.

On all three moraines, clasts were predominantly subrounded and 40-60\% of the clasts on all moraines display striae. However, there are significant differences in the basic form of the clasts between the moraines. For example, only $60 \%$ of the clasts in the innermost moraine are subrounded, compared with $80 \%$ of clasts on the two outer moraines. This is probably because the smaller contemporary glacier is less effective in erosion and transport of sediment than the larger older glaciers. This fact is compounded by the effects of nival processes. The closer proximity of the innermost moraine ridge (DN3) to the cirque back wall compared with DN2 and DN1 promotes the accumulation of talus deposits at the foot of the glacier. This results in a greater percentage of more angular clast forms. Conversely, the percentage of striated clasts is less on the older outer moraines (30-40\%) compared with the most recent moraine (60\%). This may be the result of solutional weathering and the removal of striae from the surface of limestone clasts with time.

The Debeli Namet moraines are situated up-valley from much older glacial deposits. Several sets of moraines are present down to altitudes as low as $800 \mathrm{~m}$. The nearest such moraines are situated $2 \mathrm{~km}$ down-valley and these most 
likely correlate with Pleistocene glacial deposits elsewhere in the Balkans (e.g., Hughes et al., 2006). The geochronology of the Pleistocene glacial sequence in Montenegro is currently under investigation (Hughes, 2006).

\section{The reliability and significance of the lichen-based age control}

The growth regression for the lichen species Aspicilia calcarea agg. extends back 169 years from 2006 to 1837 AD (Figure 6). This is longest known documented lichen growth regression for Aspicilia calcarea agg., around 70 years longer than previously published growth regressions (cf. Maas and Macklin, 2002). For the 50 gravestone and monument surfaces of known age, the mean percentage error between observed lichen size and the lichen size predicted using the regression was $11 \%$. This is significantly less than the conventional error estimate of lichenometric dates (Bickerton and Matthews, 1992).

The maximum thallus diameter of Aspicilia calcarea agg. obtained from the graveyard and monument sites in Montenegro used to establish the lichen growth regression was about $120 \mathrm{~mm}$ from a gravestone dated to 1837 AD (mean of the five largest lichens $=107.2 \mathrm{~mm}$ ). No surfaces of known age older than this were found in the upland areas surrounding Debeli Namet. However, Medieval tombstones (Stecci) on the Zabljak plateau, at an altitude of about $1500 \mathrm{~m}$, support lichens up to $146 \mathrm{~mm}$ in diameter. Thus, it may be possible to extend the lichen growth regression for Aspicilia calcarea agg. beyond 169 years. However, slower lichen growth as maximum size is neared has been observed in other lichen species and thus the lichen size/age relationship is likely to be curved rather than linear over the full period of growth (Mottershead and White, 1972).

At the other end of the scale, the growth regression (Equation (1)) suggests that lichen growth is observed only on surfaces older than 11.2 years. This lag between surface availability and lichen colonization is similar to the 12 years suggested by the regression between lichen size and surface age for Aspicilia calcarea agg. reported in Maas and Macklin (2002).

The strength of the regression between the mean of the five largest lichen thalli and surface age (Figure 6) suggests that statistically $92 \%$ of the variance in the diameter of the largest lichens, from a total sample size of 30 , can be attributed to variance in surface age. This method has been widely applied to date surfaces using Rhizocarpon geographicum (e.g., Maas et al., 2001; Matthews, 2005) and also using Aspicilia calcarea agg. (Merrett and Macklin, 1999; Maas and Macklin, 2002). It has been suggested that the method of choosing the mean of the five largest thalli may be biased by factors such as surface size (McCarroll, 1994; Jomelli et al., 2007). However, even though lichens were sampled from a wide range of surface sizes (from $<1$ to $5 \mathrm{~m}^{2}$ ), such a strong regression $\left(R^{2}=0.93\right.$ ) between surface age and the size of the five largest thalli from a total sample of 30 lichens would not be expected if surface size significantly affected lichen size.

Comparisons between the regressions presented in this paper and by Maas and Macklin (2002) indicate a slower lichen growth rate at the Montenegro sites compared with Crete. This may be the result of a colder climate at the Montenegro sites because of higher altitude and higher latitude. Lichen growth is known to be affected by a wide variety of environmental factors, especially moisture conditions (Haines-Young, 1983; Innes, 1985a, 1985b). Regional homogeneity (Matthews, 2005) is promoted in this study because the lichen growth curve is generated from sites in the 'periglacial zone' (Belj and Kolcakovski, 1997) over a range of only $800 \mathrm{~m}$ altitude (1400-2200 m a.s.1.). If a growth curve were generated using lichens from a greater altitudinal range, then assumptions of regional homogeneity would probably have been compromised, but this was not the case.

\section{The recent behaviour of the Debeli Namet glacier and climate change in the wider region}

The $1878 \mathrm{AD}$ and $1904 \mathrm{AD}$ lichen ages for the Debeli Namet moraines (Table I) correspond to a period of cool summer temperatures identified using annually resolved proxy records from the European Alps for the period 18751925 (Wilson et al., 2005). These lichen ages also closely coincide with a period of cold summers in the eastern Mediterranean. Based on data from nine eastern Mediterranean stations, Repapis and Philandras (1988, their Figure 2) found that summer temperatures between 1880 and 1900 were particularly cold, with average temperatures about $0.4{ }^{\circ} \mathrm{C}$ lower than the $1950-1971$ mean. It is possible, therefore, that cool summer temperatures were a forcing mechanism behind glacier advance or stabilization in Montenegro during the late 19th/early 20th century. However, increased precipitation may have also been a contributory factor. For example, in the southern Balkans, the 10-year mean annual precipitation total between 1875 and 1884 was the highest of the 119 year period from 1865 to 1984 (Katsoulis and Kambetzidis, 1989, their Table VI). There is limited available data detailing summer temperature and winter precipitation for Montenegro itself for the late 19th and early 20th centuries.

Fragmentary data from the Pyrenees and the Alps suggest that minor advances occurred at about 1850, 1890, 1910 and $1925 \mathrm{AD}$ (Grove, 2004, p. 218). Given the $11 \%$ error associated with the lichen size/age regression applied to date the Debeli Namet moraines, the DN1 moraine (dated at 1878 AD) may correlate with the 1890 AD glacier advance 
observed in the Pyrenees and Alps. Similarly, the DN2 moraine (dated at 1904 AD) may correlate with the 1910 AD glacier advance in these mountains.

Whether climatic signals affecting glaciers in the Alps and Pyrenees affected those in Montenegro is open to debate. Given that small mountain glaciers are highly responsive to the local climate signal, correlations with other distant glaciers may not necessarily be expected. In fact, within the Alps and Pyrenees there was wide-ranging variation in the timing of glacier advances in different valleys during the 19th and 20th centuries (Grove, 2004). Given the error margins associated with the lichen age control (about 11\%), any correlations must be viewed as tentative.

The outer moraines in the Debeli Namet foreland (DN1), approximately dated using lichenometry to about 1878 AD (Table I), post-date the most extensive phase of Little Ice Age glaciation elsewhere in southern Europe. In the Pyrenees, Alps and Italian Appenines, the maximum Little Ice Age extent occurred during the late 18th century AD (D'Orefice et al., 2000; Nesje and Dahl, 2000, p. 141; Grove, 2004, p. 218). In the Karlica valley, several suites of moraines are situated down-valley of the Debeli Namet 1878 AD moraines (DN1). However, these older moraines are situated more than $2 \mathrm{~km}$ down-valley at an altitude of about $1900 \mathrm{~m}$ - more than $100 \mathrm{~m}$ lower than the $1878 \mathrm{AD}$ moraines. Stratigraphical equivalents to these lower moraines can be identified in most cirque-valley systems on Durmitor. Unless Little Ice Age glaciers occupied numerous valleys on Durmitor, which is very unlikely and not reported historically, then these lower moraines are very likely to be Pleistocene in age (Hughes, 2006).

The overall retreat of the Debeli Namet glacier over the past 130 years represents behaviour in common with the only other monitored glacier in the Balkans, the Zeleni Sneg glacier on Triglav in Slovenia (Gams, 1994; Gabrovec, 1998). Indeed, several other glaciers in the Mediterranean have undergone retreat since the end of the Little Ice Age, including the Corral Veleta in the Sierra Nevada of Spain (Gómez et al., 2003), several glaciers of the Alpes Maritimes (Federici and Pappalardo, 1995; Federici and Stefanini, 2001) and the Calderone glacier in the Gran Sasso of Italy (D'Orefice et al., 2000).

The effects of future global warming (Houghton, 1997) may alter the prevailing glacier-climate dynamic at the Debeli Namet site, especially if there is a long term change in either summer temperatures or winter precipitation. Alexandrov et al. (2004) detected a statistically significant increasing trend in winter precipitation for northern Bulgaria through the 20th century, although records from other sites in the northern Balkans and central Europe over the same period show evidence of decreasing winter precipitation (Tošić and Unkašević, 2005; Domonkos, 2003). If sufficiently high, increased winter precipitation may sustain glaciers such as the Debeli Namet even under warmer summer temperatures. However, modelling by Rahmstorf and Ganopolski (1999) suggests an overall drying of Europe over the next 50 years in response to a strong decline in Atlantic thermohaline ocean circulation due to a thermal effect.

The youngest moraine at the Debeli Namet site is situated close to the margins of the glacier and supports no lichens. This suggests glacier advance or stabilization within the last 11 years. A monitoring programme is underway to understand the dynamics of the Debeli Namet glacier in relation to modern climate records. Since small mountain glaciers are sensitive indicators of moisture or temperature change, the monitoring of glaciers such as the Debeli Namet is important for understanding the effects of global change in southern Europe.

\section{Conclusions}

The Debeli Namet glacier is an active glacier in the Durmitor massif, Montenegro. It has retreated from more extensive positions marked by moraines dated using lichen Aspicilia calcarea agg. to about 1878 AD and 1904 AD. These dates correspond with a period of cool summer temperatures in the eastern Mediterranean and also wet conditions, compared with 20th century averages. A moraine at the current glacier margin supports no lichens and is estimated to have formed within the last 11 years, in response to stabilization or advance of the glacier front.

\section{Acknowledgements}

This research was funded by the Peter Fleming Award of the Royal Geographical Society - Institute of British Geographers. The author was also in receipt of a Faculty of Humanities Research Fellowship at The University of Manchester whilst undertaking this research.

\section{References}

Alexandrov V, Schneider M, Koleva E, Moisselin J-M. 2004. Climate variability and change in Bulgaria during the 20th century. Theoretical and Applied Climatology 79: 133-149. 
Belj S, Kolcakovski D. 1997. The periglacial zone of high mountains of Serbia and Macedonia and its basic characteristics. Proceedings of the OM2 International Symposium, Observation of Mountain Environment in Europe, Borovetz, Bulgaria. Abstracts, p. 3.

Benedict JB. 1991. Experiments on lichen growth II. Effects of a seasonal snow cover. Arctic, Alpine and Antarctic Research 23: 189-199.

Bickerton RW, Matthews JA. 1992. On the accuracy of lichenometric dates: an assessment based on the 'Little Ice Age' moraine sequence of Nigardsbreen, southern Norway. The Holocene 2: 227-237.

Botanic Garden and Botanical Museum Berlin-Dahlem. 2007. http://www.bgbm.fu-berlin.de [5th February 2007].

Cerović B. 1986. Durmitor and the Tara Canyon. Durmitor National Park: Beograd.

Domonkos P. 2003. Recent precipitation trends in Hungary in the context of larger scale climatic changes. Natural Hazards 29: 255271.

D'Orefice M, Pecci M, Smiraglia C, Ventura R. 2000. Retreat of Mediterranean glaciers since the Little Ice Age: case study of Ghiacciaio del Calderone, Central Apennines, Italy. Arctic, Antarctic and Alpine Research 32: 197-201.

Evans DJA, Benn DI. 2004. A Practical Guide to the Study of Glacial Sediments. Arnold: London.

Federici PR. 1979. Una ipotesi di cronologia glaciale würmiana, tardo e post- würmiana nell'Appenino Centrale. Geografia Fisica Dinamica Quaternaria 2: 196-202.

Federici PR, Pappalardo M. 1995. L'evolutione recente dei ghiacciai delle Alpi Maritime. Geografia Fisica e Dinamica Quaternaria 18: 257-269.

Federici PR, Stefanini MC. 2001. Evidences and chronology of the Little Ice Age in the Argentera Massif Italian Maritime Alps. Zeitschrift für Gletscherkunde und Glazialgeologie 37: 35-48.

Gabrovec M. 1998. The Triglav glacier between 1986 and 1998. Geografski Zbornik 38: 89-110.

Gams I. 1994. Changes of the Triglav glacier in the 1955-94 period in the light of climatic indicators. Geografski Zbornik 34: 81-117.

Gellatly AF, Grove JM, Switsur VR. 1992. Mid-Holocene glacier activity in the Pyrenees. The Holocene 2: 266-270.

Gellatly AF, Smiraglia C, Grove JM, Latham R. 1994. Recent variations of Ghiacciaio del Calderone, Abruzzi, Italy. Journal of Glaciology 40: $486-490$.

Gignoux M. 1946. Une moraine de névé particulièrement typique près du Col du Lauteret (Hautes-Alpes). Comptes Rendus Sommaires, Société Géologique du France 57-58.

Giraudi C. 2005. Middle to Late Holocene glacial variations, periglacial processes and alluvial sedimentation on the higher Apennine massifs (Italy). Quaternary Research 64: 176-184.

Gómez A, Palacios D, Luengo E, Tanarro LM, Schulte L, Ramos M. 2003. Talus instability in a recent deglaciation area and its relationship to buried ice and snow cover evolution (Picacho del Veleta, Sierra Nevada, Spain). Geografiska Annaler 85A: 165-182.

González-Trueba, J. 2004. Topoclimatical factors and very small glaciers in Atlantic mountain of SW Europe: the little ice age glacier advance in Picos de Europa (NW Spain). Zeitschrift für Gletscherkunde und Glazialgeologie 39: 115-125.

Grove AT. 2001. The 'Little Ice Age' and its geomorphological consequences in Mediterranean Europe. Climatic Change 48: $121-136$.

Grove JM. 2004. Little Ice Ages: Ancient and Modern, Vols I, II. Routledge: London.

Grove JM, Gellatly AF. 1995. Little Ice Age glacier fluctuations in the Pyrenees. Zeitschrift für Gletscherkunde und Glaziolgeologie 31: 199-206.

Haines-Young RH. 1983. Size variation of Rhizocarpon on moraine slopes in southern Norway. Arctic and Alpine Research 15: $295-305$.

Houghton J. 1997. Global Warming: the Complete Briefing. Cambridge University Press: Cambridge.

Hubbard GD. 1932. Balkan studies. Geographical Review 22: 513-514.

Hughes PD. 2006. The glacial history of Montenegro. Quaternary Newsletter 108: 40-42.

Hughes PD, Woodward JC, Gibbard PL, Macklin MG, Gilmour MA, Smith GR. 2006. The glacial history of the Pindus Mountains, Greece. Journal of Geology 114: 413-434.

Innes JL. 1985a. Moisture availability and lichen growth: the effects of snow cover and streams on lichenometric measurements. Arctic and Alpine Research 17: 417-424.

Innes JL. 1985b. Lichenometry. Progress in Physical Geography 9: 187-254.

Jomelli V, Grancher D, Naveau P, Cooley D, Brunstein D. 2007. Assessment study of lichenometric methods for dating surfaces. Geomorphology 86: 131-143. DOI: 10.1016/j.geomorph.2006.08.010

Katsoulis BD, Kambetzidis HD. 1989. Analysis of the long-term precipitation series at Athens. Greece. Climatic Change 14: $263-290$.

Louis H. 1930. Morphologische Studien in Südwest-Bulgarien. Geographische Abhandlungen, Stuttgart, Series 3, No. 2.

Maas GS, Macklin MG, Warburton J, Woodward JC, Meldrum EA. 2001. 300-year history of flooding in Andean mountain river system: the Rio Alizos, southern Bolivia. In River Basin Sediment Systems: Archives of Environmental Change, Maddy D, Macklin G, Woodward JC (eds). Balkema: Rotterdam; 297-323.

Maas GS, Macklin MG. 2002. The impact of recent climate change on flooding and sediment supply within a Mediterranean mountain catchment, southwestern Crete, Greece. Earth Surface Processes and Landforms 27: 1087-1105.

Marovic M, Markovic M. 1972. Glacial morphology of the Durmitor Mt. wider area. Geoloski Anali Balkanskog Poluostrva XXXVII: 3748 (in Serbian).

Matthews JA. 2005. 'Little Ice Age' glacier variations in Jotunheim, southern Norway: a study in regionally controlled lichenometric dating of recessional moraines with implications for climate and lichen growth rates. The Holocene 15: 1-19.

McCarroll D. 1994. A new approach to lichenometry: dating single-age and diachronous surfaces. The Holocene 22: $383-396$.

Merrett SP, Macklin MG. 1999. Historic river response to extreme flooding in the Yorkshire Dales, northern England. In Fluvial Processes and Environmental Change, Brown AG, Quine TA (eds). Wiley: Chichester; 345-360.

Mottershead DN, White ID. 1972. The lichenometric dating of glacier recession, Tunsbergdal Southern Norway. Arctic and Alpine Research 54A: $47-52$. 
Nesje A, Dahl SO. 2000. Glaciers and Environmental Change. Arnold: London.

Nicod J. 1968. Premières recherches de morphologie karstique dans le massif du Durmitor. Meditérranée 3: 187-216.

Rahmstorf S, Ganopolski A. 1999. Long-term global warming scenarios computed with an efficient coupled model. Climatic Change 43: 353-367.

Repapis CC, Philandras CM. 1988. A note on the air temperature trends of the last 100 years as evidenced in the Eastern Mediterranean time series. Theoretical and Applied Climatology 39: 93-97.

Roth von Telegd K. 1923. Das albanisch-montenegrinische Grenzgebiet bei Plav (Mit besonderer Berücksichtigung der Glazialspuren). In Beiträge zur Geologie von Albanien, Neues Jahrbuch für Mineralogie 1, Nowack E (ed.). Schweizerbart: Stuttgart; $422-494$.

Serrano E, González-Trueba JJ. 2005. Assessment of geomorphosites in natural protected areas: the Picos de Europa National Park (Spain). Geomorphologie: Relief, Processus, Environnement 3: 197-208.

Shakesby RA, Matthews JA, McCarroll D. 1995. Pronival ('protalus') ramparts in the Romsdalsalpane, Southern Norway: forms, terms, subnival processes, and alternative mechanisms of formation. Arctic and Alpine Research 27: 271-282.

Tošić I, Unkaševic M. 2005. Analysis of precipitation series for Belgrade. Theoretical and Applied Climatology 80: 67-77.

Velchev A. 1999. Glacial and cryogenic relief in some parts of the Musala watershed in Rila Mountain. In Annuair de L. Universite de Sofia 'St. Kliment Ohridski', Faculte de Geologie et Geographie, Book 2 - Geographie, Vol. 89; 7-21 (in Bulgarian - abstract and summary in English).

Wilson R, Frank D, Topham J, Nicolussi K, Esper J. 2005. Spatial reconstruction of summer temperatures in Central Europe for the last 500 years using annually resolved proxy records: problems and opportunities. Boreas 34: 490-497.

Xoplaki E, Maheras P, Luterbacher J. 2001. Variability of climate in meridional Balkans during the periods 1675-1715 and 1780-1830 and its impact on human life. Climatic Change 48: 581-615. 